\title{
Ethnic inequalities in time to diagnosis of cancer: a systematic review
}

\author{
Tanimola Martins ${ }^{*}{ }^{\dagger}$, William Hamilton ${ }^{\dagger}$ and Obioha C Ukoumunne ${ }^{\dagger}$
}

\begin{abstract}
Background: Minimising diagnostic delays in cancer may help improve survival. Ethnic minorities have worse outcomes in some cancer types when compared to the majority; this may relate in part to differences during the diagnostic phase. Only a few British studies have specifically explored this relationship, and no synthesis of these exists. The present study aimed to systematically review evidence on ethnic inequalities in cancer diagnosis, focussing on patient and primary care intervals of diagnosis.

Methods: Six electronic databases were searched. Included studies were those conducted in the UK or elsewhere (where access to healthcare is comparable to the NHS) and those that described a time element during diagnosis. Study quality was evaluated using the Critical Appraisal Skills Programme (CASP) checklist for cohort studies and synthesis method was narrative.
\end{abstract}

Results: Seven of 8,520 studies retrieved by our search met the review criteria; six conducted in the UK, and one in New Zealand. Five (including one covering several sites) focused on breast cancer, one on prostate, and one on oesophagogastric cancer. The studies employed different methods of ascertainment and definition of ethnic groups and defined diagnostic delay in a non-standardised way; therefore, narrative synthesis was performed. In breast cancer, three studies reported longer diagnostic intervals among ethnic minorities and two found no evidence of differences by ethnicity. There was some evidence of longer diagnostic and referral intervals among ethnic minorities in oesophagogastric and colorectal cancers, but no evidence of this in prostate, non-Hodgkin's lymphoma, lung, and ovarian cancers. None of the studies identified shorter patient or primary care intervals in ethnic minorities.

Conclusions: Existing studies provide insufficient evidence to confirm or refute ethnic inequalities in diagnostic intervals of cancer. Further studies are necessary to examine common cancer types including those frequently found in ethnic minorities (in addition to those covered here) and using current definitions of intervals in cancer diagnosis.

Keywords: Health inequality, Ethnicity, Cancer, Diagnostic delay, Diagnostic intervals

\section{Background}

Minimising delays in cancer diagnosis - particularly, patient and primary care delays - may help improve cancer outcomes in the UK, which at the moment lag behind most other countries in Europe [1,2]. Recent studies estimate that 5,000 to 10,000 cancer deaths could be prevented annually in the UK if efforts to expedite diagnosis succeed $[1,2]$. As some ethnic minorities suffer more illness and report worse experience of the National Health Services (NHS) [3], it is possible this will extend

\footnotetext{
* Correspondence: tom205@exeter.ac.uk

${ }^{\dagger}$ Equal contributors

University of Exeter Medical School, Veysey Building, Salmon Pool Lane, Exeter, UK
}

to cancer diagnostics, contributing to the UK's poor outcomes. Few UK studies have specifically explored this relationship, with most evidence coming from the US [4]. The findings of these studies may not be generalisable to the UK, given the differences in the organisation and operations of the US and UK health care systems in addition to the differences in nature and composition of ethnic groups.

Access to health care in the UK is universally free at the point of delivery with an ethos of equity in service provision. In theory, this should reduce any disparity in cancer diagnostics. There is, however, a greater incidence of advanced-stage diagnoses of female breast 
cancer and prostate cancers among ethnic minority groups compared to the majority [5,6], although these studies did not report an explanation for their findings. The reason for such disparities in disease stage is unclear given that pre-referral consultation rates are markedly higher among ethnic minority groups with cancer [7]. It is unknown whether this is the case for other cancer sites, including those found to be more common in ethnic minority groups - e.g., mouth, liver, stomach, oesophagogastric and ovarian cancers $[8,9]$.

\section{Aim of review}

The present study aimed to gather and critically appraise existing evidence on inequalities in cancer diagnosis by ethnic groups in the UK and in countries with a similar health care system - in terms of costs, availability and access [10], specifically examining literature reporting time to diagnosis of the cancer. We used the schema of intervals in cancer diagnosis described by Olesen and colleagues, and illustrated in Figure 1 [11].

\section{Methods}

Between 23rd February and 6th March 2012, a systematic search of six electronic databases (EMBASE, MEDLINE, PsycINFO, Web of Knowledge, CINAHL and Campbell Collaboration) was performed. Table 1 includes the list of search terms used. Inclusion criteria were: studies focused on adult primary cancers; published from January 2000 onwards - marking the start of major reforms in cancer diagnosis in the UK; investigated ethnic differences in the interval between symptom onset and GP presentation or the interval between GP presentation and referral or diagnosis. Exclusion criteria were: studies focused on secondary cancers; cancer incidence and survival; cancer genetics; screening; prevention; treatment or co-morbidities; studies from America (other than Canada), Africa and Asia, Middle East and Eastern Europe. Our final list of countries largely matches those countries within the International Cancer Benchmarking Partnership, which seeks to explain international differences in cancer outcomes [1]. Two reviewers (TM and CS) independently reviewed the title, abstract and full text articles (where necessary) to determine studies inclusion eligibility. Studies that appeared to meet the inclusion criteria or where a decision could not be made based on the title and/or abstract were selected for full-text review to identify those for the final analysis.

Given the methodological heterogeneity of the studies, a quantitative synthesis was not possible, so we performed a narrative synthesis, using the framework of Rodgers and colleagues [12]. Data from included studies were extracted, collated and tabulated by a single extractor (TM). The primary outcome was the interval between first symptom experience and eventual diagnosis, subdivided where possible into patient delay and primary care delay [13], with the main explanatory variable being ethnicity. The only subgroup analysis planned was by cancer site; however, the heterogeneity of the studies precluded formal meta-analysis, so we performed our

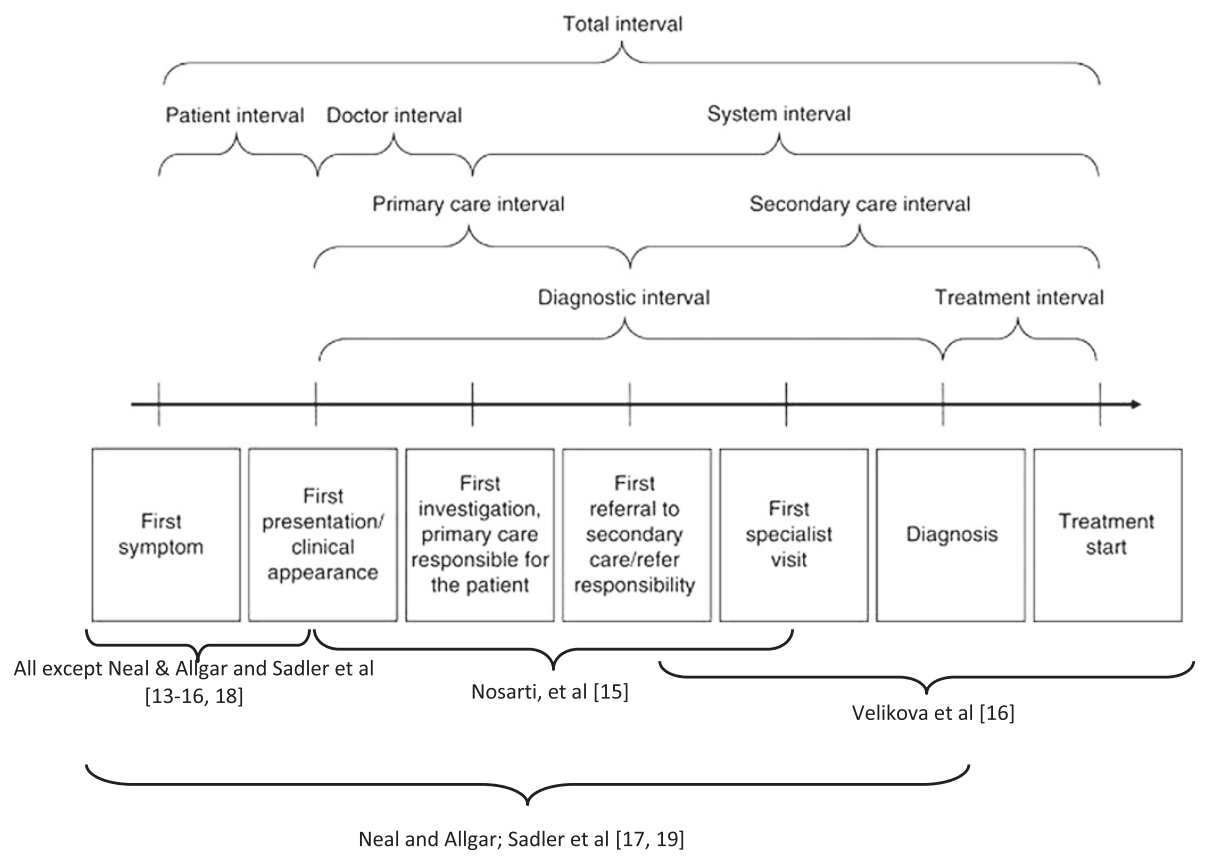

Figure 1 Milestone and time intervals from symptoms onset to treatment. 


\begin{tabular}{|c|c|c|c|}
\hline Population & Exposure & Comparison & Outcome \\
\hline $\begin{array}{l}\text { Terms relating to cancer : Cancer, } \\
\text { Neoplasm, Malignant Neoplasm, tumour, } \\
\text { Malignant tumour, Astrocytoma, } \\
\text { Adenocarcinoma, Glioma, Mesothelioma, } \\
\text { Medulloblastoma, Myeloma, Melanoma, } \\
\text { Neuroblastoma, Sarcoma, Nonmelanoma, } \\
\text { Osteosarcoma, Teratoma, Seminoma, } \\
\text { Hodgkin, leuk?emia, Lymphoma, } \\
\text { Retinoblastoma }\end{array}$ & $\begin{array}{l}\text { Terms defining ethnic minorities in the } \\
\text { UK: Ethnic* Race* Cultural groups, white } \\
\text { Irish, other whites, African British, Black* } \\
\text { Black Caribbean, British Caribbean, } \\
\text { Asian*, Indian, British, Indian, Pakistani, } \\
\text { British Pakistani, Bangladeshi, British, } \\
\text { Bangladeshi, Chinese, Mixed race }\end{array}$ & $\begin{array}{l}\text { Ethnic majority in } \\
\text { the UK: Ethnic* } \\
\text { Race* Cultural }^{*} \text { ' } \\
\text { groups, White } \\
\text { British }\end{array}$ & $\begin{array}{l}\text { Terms relating to intervals of cancer } \\
\text { diagnosis: Duration of symptom; Interval } \\
\text { of symptoms; Time; Delay; Late; Postpone; } \\
\text { and Wait to Symptom, Presentation, } \\
\text { Attendance, Consultation, Appointment, } \\
\text { Diagnosis, Detection, Treatment, } \\
\text { Intervention, Referral. Other terms; Gate } \\
\text { keeping, primary care }\end{array}$ \\
\hline
\end{tabular}

narrative synthesis using the cancer sites stratified by diagnostic intervals studied.

\section{Quality assessment}

This used the Critical Appraisal Skills Programme (CASP) checklist for cohort studies, interpreted to fit our study topic (see rows 1 and 2 in Table 2 for details). Each retrieved article was independently appraised by two reviewers (TM and OU) and was classified as either "satisfactory", "medium" or "high" quality paper depending on the extent to which the checklist items were met, and also on the level of concerns raised about their methodology in general. For instance, a concern was raised where authors classified ethnic groups differently to the contemporary ethnic classifications in their population.

\section{Results}

\section{Study characteristics}

In total, 8,520 articles were identified from the search strategy. After screening the titles and abstracts, and removing the duplicates, 8,489 irrelevant articles were excluded. The remaining 31 articles were then retrieved for full text review, and seven met the inclusion criteria and were included in the analysis (see flow chart in Figure 2).

Characteristics of the selected studies are shown in Table 3 with results of the quality assessment in Table 2 . All seven studies were observational, with retrospective cohort designs, using hospital records, cancer registry records, survey questionnaires and in-depth interviews. Six were carried out in the UK, and one in New Zealand. Five studies [14-18] investigated ethnic differences in breast cancer diagnosis while the remaining two focused on prostate [20] and oesophagogastric cancer [19] respectively. Neal and Allgar studied several other cancer sites in addition to breast: lung, prostate, colorectal nonHodgkin's lymphoma (NHL) and ovarian [18].

Five studies [14-17,20] investigated ethnic differences in patient delay, that is, delay occurring in the interval between first symptom and first GP presentation (see Figure 1). Two of these [16,17] also examined ethnic differences in delay following the first GP presentation, but their definitions of these time periods differed. Nosarti et al. defined delay occurring in the interval between the first GP presentation and first specialist visit as system delay [17]. Velikova et al. defined the interval between first GP referral and the first hospital visit as provider's delay [16]. Neither of these correspond with current definitions [13]. The remaining two studies took slightly different approaches in their definition of delay intervals. Sadler and colleagues used patients' referral routes to the hospital as surrogate measures of primary care delay [19]. They considered two-week waits (2WW) or 'Direct Access Oesophagogastro-duodenoscopy' (OGD) as optimal routes to diagnosis, while waiting for routine appointments and acute admission were both considered sub-optimal. In addition, they reported ethnic differences in total diagnostic interval, which is the interval from first symptom to diagnosis. Similarly, Neal and Allgar reported the same interval, naming it pre-hospital delay [18]. For the rest of this paper, we have renamed these 'the diagnostic interval'. They also reported ethnic differences in referral delay, which they defined as the waiting time from first GP visit to first hospital appointment.

\section{Assessment of study quality}

Overall, none of our seven studies had fewer than two concerns and none could be classified as "high quality" due to the systematic flaws in their methodology - as highlighted by the CASP assessment shown in Table 2. Only one study [18] had relatively low risk of bias, and was classified as "medium quality". It had a large sample size, investigated several cancer sites, and classified ethnic groups in a way that was applicable to their target population. However, they only reported ethnic differences in pre-hospital delay, which includes factors relating to the patient, primary and secondary care and health care system making it difficult to ascertain where differences have arisen from. The remaining six studies had a greater overall risk of bias and were evaluated as "satisfactory".

\section{Ethnic differences in delay intervals by cancer sites Breast}

Of the five studies that investigated ethnic differences in breast cancer diagnosis, two $[16,18]$ found evidence of longer intervals in ethnic minority groups compared to the 
Table 2 Quality of studies

\begin{tabular}{|c|c|c|c|c|c|c|c|}
\hline CASP question & $\begin{array}{l}\text { Was the cohort } \\
\text { representative of a } \\
\text { defined population? }\end{array}$ & $\begin{array}{c}\text { Was } \\
\text { everybody } \\
\text { included }\end{array}$ & $\begin{array}{l}\text { Was the exposure } \\
\text { accurately measured } \\
\text { to minimize bias? }\end{array}$ & $\begin{array}{l}\text { Was the outcome } \\
\text { precisely measured } \\
\text { to minimize bias? }\end{array}$ & $\begin{array}{l}\text { Have the authors identified } \\
\text { and adjusted for all key } \\
\text { confounding factors? }\end{array}$ & $\begin{array}{c}\text { How precise are } \\
\text { the results? }\end{array}$ & $\begin{array}{l}\text { Overall } \\
\text { quality }\end{array}$ \\
\hline $\begin{array}{l}\text { Adapted } \\
\text { question }\end{array}$ & Unchanged & $\begin{array}{c}\text { Were all eligible } \\
\text { cancer patients } \\
\text { studied? }\end{array}$ & $\begin{array}{c}\text { Was ethnicity } \\
\text { defined according to } \\
\text { contemporary groupings? }\end{array}$ & $\begin{array}{l}\text { Was diagnostic intervals } \\
\text { measured to Olsen and } \\
\text { colleagues framework? }\end{array}$ & $\begin{array}{l}\text { Unchanged. Key confounders include: } \\
\text { age, gender, SES, co-morbidity, } \\
\text { healthcare system, family history of } \\
\text { cancer and tumour growth rates }\end{array}$ & $\begin{array}{l}\text { Have they presented estimates } \\
\text { of association along with the } \\
\text { confidence intervals? Are the } \\
\text { confidence intervals narrow? }\end{array}$ & Unchanged \\
\hline $\begin{array}{l}\text { Rajan et al. } \\
\text { (2011) [14] }\end{array}$ & Met & Unmet & Partially met & Met & Unmet & Unmet & Sat \\
\hline $\begin{array}{l}\text { Meechan et al. } \\
\text { (2002) [15] }\end{array}$ & Met & Partially met & Met & Met & Unmet & Unmet & Sat \\
\hline $\begin{array}{l}\text { Velikova et al., } \\
\text { (2004) [16] }\end{array}$ & Met & Partially met & Unmet & Partially met & Partially met & Partially met & Sat \\
\hline $\begin{array}{l}\text { Nosarti et al. } \\
(2000) \text { [17] }\end{array}$ & Met & Met & Met & Partially met & Partially met & Unmet & Sat \\
\hline $\begin{array}{l}\text { Neal and Allgar } \\
\text { (2005) [18] }\end{array}$ & Met & Met & Met & Partially met & Partially met & Partially met & Med \\
\hline $\begin{array}{l}\text { Sadler et al. } \\
\text { (2009) [19] }\end{array}$ & Met & Met & Met & Partially met & Unmet & Unmet & Sat \\
\hline $\begin{array}{l}\text { Metcalfe et al. } \\
\text { (2008) [20] }\end{array}$ & Met & Partially met & Partially met & Met & Partially met & Met & Sat \\
\hline
\end{tabular}

Note: Sat satisfactory; Med medium quality paper. 
white majority. Neal and Allgar reported that ethnic minority women of Asian and black origin were more likely to experience longer diagnostic intervals, even after adjustment for marital status, gender, age and socioeconomic status (SES) $(\mathrm{P}<0.001)$ [18]. Similarly, Velikova et al. found longer patient delay in Asian women compared to non-Asian (median of 61 days vs. median of 31 days, $\mathrm{P}=0.005$ ) even after adjustment for SES, age and health care settings [16]. Another study, Rajan et al., found that nearly half (45\%) of the Asian women in their West Yorkshire (UK) cohort delayed over two months before presenting with breast symptoms [14]. They labelled this as 'delay' but without providing data for non-Asians. The remaining two studies $[15,17]$ found no difference by ethnicity.

\section{Oesophagogastric}

Sadler and colleagues found evidence that Asians (13\%) were less likely to take the optimal route to diagnosis (OGD and 2WW) compared to blacks (49\%) and
Caucasians (39\%); $\mathrm{P}=0.01$ [19]. They also found that Asians (39\%) and blacks (45\%) were less likely to be diagnosed within three months of symptom discovery compared to Caucasians (63\%); $\mathrm{P}=0.03$ ).

\section{Colorectal}

Neal and Allgar reported longer referral delay among Asians and Blacks even after adjustment for marital status, gender, age and SES $(P=0.02)$ [18]. No difference by ethnicity was found in pre-hospital delay.

\section{Other cancer sites}

For lung, prostate, NHL, and ovarian cancers no evidence was found of differences in delay interval across ethnic groups $[18,20]$.

\section{Discussion}

Health service provision must be culturally sensitive if health inequalities are to be reduced and eliminated.

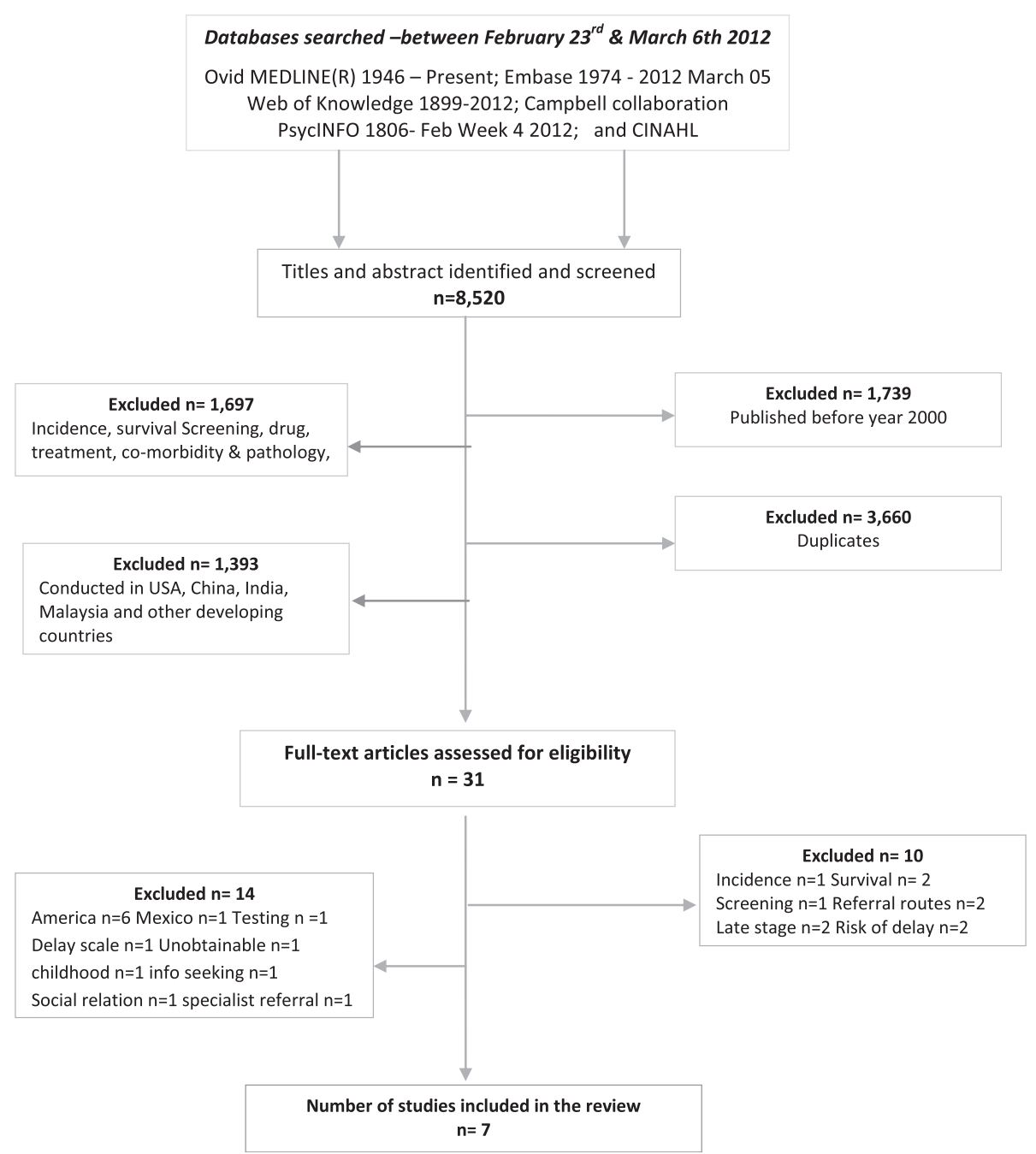

Figure 2 Flow chart of study selection process. 
Table 3 Characteristics and findings of reviewed studies

\begin{tabular}{|c|c|c|c|c|c|c|c|c|c|}
\hline \multirow[t]{2}{*}{ Author } & \multirow[t]{2}{*}{ Country } & \multirow[t]{2}{*}{ Title/aim } & \multirow[t]{2}{*}{ Site } & \multirow{2}{*}{$\begin{array}{l}\text { Sample size ( } n \text { ) } \\
\text { gender age }\end{array}$} & \multirow[t]{2}{*}{ Method } & \multicolumn{2}{|c|}{ Ethnic groups } & \multirow{2}{*}{$\begin{array}{l}\text { Relevant outcome } \\
\text { measures }\end{array}$} & \multirow[t]{2}{*}{ Results } \\
\hline & & & & & & Exposure & Comparison & & \\
\hline $\begin{array}{l}\text { Rajan et al. } \\
\text { (2011) [14] }\end{array}$ & $\begin{array}{l}\text { UK (West } \\
\text { Yorkshire) }\end{array}$ & $\begin{array}{l}\text { To improve knowledge } \\
\text { about late presentation } \\
\text { and management of } \\
\text { breast cancer among } \\
\text { South Asian women. }\end{array}$ & Breast & $\begin{array}{l}n=1,630 \\
\text { ( } 36 \text { South Asian } \\
\text { women) all } \\
\text { female median } \\
\text { age }=53.5 \text { years }\end{array}$ & $\begin{array}{l}\text { Retrospective: } \\
\text { Breast cancer } \\
\text { waiting list } \\
\text { database and } \\
\text { case notes }\end{array}$ & $\begin{array}{l}\text { South Asian } \\
\text { women; Indians } \\
\text { and Pakistanis }\end{array}$ & $\begin{array}{l}\text { None; throughout } \\
\text { the paper, including } \\
\text { the title, the authors } \\
\text { imply South Asian } \\
\text { women had more } \\
\text { delay }\end{array}$ & $\begin{array}{l}\text { Duration of breast } \\
\text { symptoms prior } \\
\text { to presentation } \\
\text { within primary } \\
\text { care }\end{array}$ & $\begin{array}{l}45 \% \text { of Asian women delayed } \\
\text { symptoms beyond } 8 \text { weeks before } \\
\text { visiting their GP }\end{array}$ \\
\hline $\begin{array}{l}\text { Meechan et al. } \\
\text { (2002) [15] }\end{array}$ & $\begin{array}{l}\text { New } \\
\text { Zealand }\end{array}$ & $\begin{array}{l}\text { Delay in seeking medical } \\
\text { care for self-detected } \\
\text { breast symptoms in } \\
\text { New Zealand women. }\end{array}$ & Breast & $\begin{array}{l}\mathrm{n}=85 \text { all } \\
\text { female mean } \\
\text { age }=38 \text { years }\end{array}$ & $\begin{array}{l}\text { Retrospective: } \\
\text { questionnaire } \\
\text { \& patient record }\end{array}$ & $\begin{array}{l}\text { Minority New } \\
\text { Zealanders - Maori, } \\
\text { Pacific \& Asian/ } \\
\text { Indian }\end{array}$ & $\begin{array}{l}\text { European New } \\
\text { Zealanders }\end{array}$ & Patient delay & $\begin{array}{l}\text { No difference in patient delay by } \\
\text { ethnicity. }\end{array}$ \\
\hline $\begin{array}{l}\text { Velikova et al. } \\
\text { (2004) [16] }\end{array}$ & $\begin{array}{l}\text { UK (South } \\
\text { Yorkshire) }\end{array}$ & $\begin{array}{l}\text { To describe the effect of } \\
\text { ethnicity on tumour } \\
\text { stage, treatment, patient } \\
\text { and providers delays in } \\
\text { diagnosis of breast cancer }\end{array}$ & Breast & $\begin{array}{l}\mathrm{n}=16,879 \text { all } \\
\text { female mean } \\
\text { age }=49.7 \text { years } \\
\text { in Asians and } \\
62 \text { years in } \\
\text { non-Asians }\end{array}$ & $\begin{array}{l}\text { Retrospective: } \\
\text { Cancer registry } \\
\text { data }\end{array}$ & South Asian & Non-Asian & $\begin{array}{l}\text { Patients and } \\
\text { providers delays } \\
\text { to diagnosis }\end{array}$ & $\begin{array}{l}\text { After adjusting for, age, SES and } \\
\text { health care settings; patient delay } \\
\text { was longer in Asian than in } \\
\text { non -Asian women (median of } \\
61 \text { days vs. median of } 31 \text { days, } \\
P=0.005 \text { ) }\end{array}$ \\
\hline $\begin{array}{l}\text { Nosarti et al. } \\
(2000)[17]\end{array}$ & UK & $\begin{array}{l}\text { To identify factors } \\
\text { associated with delay } \\
\text { in presentation and } \\
\text { assessment of } \\
\text { symptomatic breast } \\
\text { cancer }\end{array}$ & Breast & $\begin{array}{l}\mathrm{n}=692 \text { all } \\
\text { female median } \\
\text { age }=49 \text { years }\end{array}$ & $\begin{array}{l}\text { Retrospective: } \\
\text { Interview, GP \& } \\
\text { hospital records }\end{array}$ & $\begin{array}{l}\text { African Afro- } \\
\text { Caribbean } \\
\text { and Asian }\end{array}$ & $\begin{array}{l}\text { British and } \\
\text { other white }\end{array}$ & $\begin{array}{l}\text { Patient and } \\
\text { system delay }\end{array}$ & $\begin{array}{l}\text { Ethnicity were non-contributory } \\
\text { to patient delay in breast cancer }\end{array}$ \\
\hline $\begin{array}{l}\text { Neal and Allgar } \\
\text { (2005) [18] }\end{array}$ & UK & $\begin{array}{l}\text { To explore the } \\
\text { relationship between } \\
\text { socio-demographic } \\
\text { factors \& delays in the } \\
\text { diagnosis of six cancers }\end{array}$ & $\begin{array}{l}\text { Breast, lung, } \\
\text { colorectal, } \\
\text { prostate } \\
\text { NHL, and } \\
\text { ovarian }\end{array}$ & $\begin{array}{l}n=65,192 \\
\text { male \& female } \\
\text { all age groups }\end{array}$ & $\begin{array}{l}\text { Retrospective: } \\
\text { Analysis of the } \\
\text { National Survey } \\
\text { Data }\end{array}$ & $\begin{array}{l}\text { Blacks - Africans, } \\
\text { Caribbean \& others } \\
\text { blacks. South } \\
\text { Asians -Indian, } \\
\text { Pakistani, } \\
\text { Bangladeshi, } \\
\text { others. }\end{array}$ & Whites & $\begin{array}{l}\text { Total, pre-hospital, } \\
\text { referral and } \\
\text { secondary care } \\
\text { delay }\end{array}$ & $\begin{array}{l}\text { After adjusting for marital status, } \\
\text { gender, age and SES, Asian and } \\
\text { black had longer pre-hospital } \\
\text { delays for breast cancer in women } \\
(P=0.001) \text { and longer referral delay } \\
\text { for colorectal cancer }(P=0.02) \text {. No } \\
\text { evidence of difference for lung, } \\
\text { prostate, NHL and ovarian. }\end{array}$ \\
\hline $\begin{array}{l}\text { Sadler et al. } \\
\text { (2009) [19] }\end{array}$ & $\begin{array}{c}\text { UK } \\
\text { (Birmingham) }\end{array}$ & $\begin{array}{l}\text { The effect of ethnicity } \\
\text { on the presentation } \\
\text { and management of } \\
\text { oesophageal and gastric } \\
\text { cancers: A UK perspective }\end{array}$ & $\begin{array}{l}\text { oesophageal } \\
\text { \& gastric }\end{array}$ & $\begin{array}{l}\mathrm{n}=244 \text { male } \& \\
\text { female median } \\
\text { age }=71 \text { years }\end{array}$ & $\begin{array}{l}\text { Retrospective: } \\
\text { Case-note audit }\end{array}$ & Asians and Blacks & Caucasians & $\begin{array}{l}\text { Referral routes } \\
\text { and total } \\
\text { diagnostic } \\
\text { interval }\end{array}$ & $\begin{array}{l}\text { Asians and Blacks compared to } \\
\text { Caucasians were less likely to be } \\
\text { diagnosed within } 3 \text { months of } \\
\text { symptom discovery ( } P=0.03 \text { ) and } \\
\text { less likely to take the optimal } \\
\text { route to diagnosis }(p=0.01) \text {. }\end{array}$ \\
\hline $\begin{array}{l}\text { Metcalfe et al. } \\
\text { (2008) [20] }\end{array}$ & UK & $\begin{array}{l}\text { To examine the pathways } \\
\text { followed by black and } \\
\text { white men to prostate } \\
\text { cancer diagnosis }\end{array}$ & Prostate & $\begin{array}{l}\mathrm{n}=1,866 \\
\text { men median } \\
\text { age }=67.9 \text { years } \\
\text { in blacks } \\
73.3 \text { years in } \\
\text { whites }\end{array}$ & $\begin{array}{l}\text { Retrospective: } \\
\text { Questionnaire, } \\
\text { hospital records } \\
\text { and cancer } \\
\text { registry data }\end{array}$ & Black men & White men & $\begin{array}{l}\text { Delay between } \\
\text { onset of } \\
\text { symptoms and } \\
\text { first GP } \\
\text { presentation. }\end{array}$ & $\begin{array}{l}\text { After adjusting for age and hospital } \\
\text { centre, no significant difference } \\
\text { between white and black men in } \\
\text { patient delay (odds ratio: 0.82; } \\
95 \% \text { Cl: } 0.57 \text { to 1.19) }\end{array}$ \\
\hline
\end{tabular}


This is important in the UK (and other countries) as it becomes even more multicultural with considerable increases in ethnic minority population. Few UK studies have specifically explored ethnic inequalities in cancer diagnosis, and to the best of our knowledge no synthesis of evidence exists.

\section{Strengths and limitations}

Our rigorous search strategy, and explicit inclusion/exclusion criteria, quality assessment of included studies and narrative synthesis followed best practice. Our search identified only a small number of studies, the bulk of which were (unsurprisingly) conducted in the UK, given that the UK is one of the most ethnically diverse countries in Europe. Our decision to omit American studies (other than Canada) was based on their very different health care system and ethnic groupings; it considerably reduced the number of selected studies, although this reflected our research question of whether there are ethnic inequalities in the time to diagnosis of cancer within a free health care system. A limitation was that most studies focused on breast cancer, reducing the scope of the review. Furthermore, any review is only as good as the studies it finds. Our selections differed considerably in methodology - especially in the definitions of intervals before diagnosis, which made quantitative synthesis inappropriate, and complicated the narrative synthesis. Participants' ethnic groups were poorly defined in some studies; at times there was a mismatch between the ethnic groupings used for the study and contemporary ethnic groupings used in the whole population from which their sample was drawn $[16,20]$. We interpreted the CASP quality instrument for this review - primarily to fit our study topic: it is unlikely these minor changes led to more studies 'failing' our quality assessment. Finally, publication bias is possible as studies showing no association between ethnicity and cancer diagnostic delays may have failed to be published, leaving us with disproportionately positive studies.

\section{Comparison with previous studies}

Two previous reviews [21,22] have examined delays in cancer diagnosis, although neither examined ethnicity. In both (like in the present review), the intervals were defined in a nonstandard way. This is understandable, as terminology in this subject was ill-defined before the advent of the Aarhus statement [13]. This provides more precise description of milestones along the cancer diagnostic pathway, as well as describing preferred research methodologies. In an assessment of primary care use prior to cancer diagnosis, Lyratzopoulos and colleagues found that ethnic minority groups were more likely to have consulted their GPs three or more times before hospital referral (odds ratio for Asian vs. white 1.73,
$1 \cdot 45$ to $2 \cdot 08 ; \mathrm{p}<0 \cdot 0001$; odds ratio for black vs. white $1 \cdot 83,1 \cdot 51$ to $2 \cdot 23$; $\mathrm{p}<0 \cdot 0001$. This study did not report durations or intervals to diagnosis, so would not have met our inclusion criteria, though its results are consistent with our findings.

\section{Review findings}

We found limited, methodologically-weak evidence for ethnic inequalities in cancer diagnosis, though largely for breast cancer. Conversely, the review found no evidence to suggest that ethnic minority groups were doing better at any stage of cancer diagnostic pathway. For breast cancer, three (of five studies) found longer patient and pre-hospital delays in ethnic minority women compared to their white counterparts; while the remaining two reported no difference. The latter two studies sampled participants from a relatively small number of women referred to a specialist clinic for further investigation. It is well-recognised that cancer patients may take alternative routes to diagnosis, such as routine specialist clinics or emergency admission; these will have been omitted from the two studies based in specialist clinics $[23,24]$. Furthermore, both studies were based on interviewing patients about their delay experiences whilst in the specialist waiting room. Therefore, their findings may have been influenced by selection and recall biases. In contrast, the three studies finding differences in diagnostic intervals across ethnic groups recruited participants with definite diagnosis of breast cancer, and then surveyed or examined their medical record for important dates of presentation and referral.

\section{Conclusion}

Redressing inequalities in health (including those relating to ethnic diversity) is central to most reforms and strategies on health and social services in the UK. However, as the government progresses with the implementation of its austerity measures (with considerable cuts to health care expenditure) there are concerns that providers may prioritise differently. Potentially, some services including those intended to meet the specific health care needs of ethnic minority communities may be compromised - e.g., tailored services for language and communication needs, and the need for gender-specific providers. To ensure that policies are tailored to need, sufficient evidence is crucial. If existing evidence suggests ethnic variations in diagnostic delay, then policies aimed at promoting early diagnosis should also target the affected groups.

This review found some evidence for ethnic differences in cancer diagnosis with ethnic minorities taking longer to diagnosis. The evidence was largely in breast cancer patients. However, these findings are from methodologically heterogeneous studies, with different 
measures of delay. The studies had designs that are prone to bias. Future studies will need to examine the subject using a clearly defined and representative sample of ethnic minority groups, incorporate cancer types that are more common in ethnic minority groups and employ the definitions of cancer diagnostics in the Aarhus statement. This should be possible with the advent of large linked datasets containing routine healthcare data (e.g., the Diagnostic Imaging Dataset which incorporates ethnicity as a variable).

\section{Competing interests}

The authors declare that they have no competing interests.

\section{Authors' contributions}

TM was involved in all aspects. WH participated in study design, data interpretation and preparation/revision of the manuscript. OU participated in study design, data extraction, assessment of study quality, and manuscript preparation. All authors read and approved the final manuscript.

\section{Acknowledgements}

We thank Professor Richard Neal for his contributions to the search terms for cancer and delay intervals. We also acknowledge Catherine Stabb for helping with data extraction and study selection. Members of the Peninsular College of Medicine and Dentistry Synthesis team helped review the search strategy. $\mathrm{OU}$ is supported by the Peninsula Collaboration for Leadership in Applied Health Research and Care, a collaboration between the University of Exeter, University of Plymouth, and National Health Service South West, funded by the National Institute for Health Research.

\section{Funding body}

The Policy Research Unit (PRU) in Cancer Awareness, Screening and Early Diagnosis receives funding for a research programme from the Department of Health Policy Research Programme. It is collaboration between researchers from seven institutions (Queen Mary University of London, UCL, King's College London, London School of Hygiene and Tropical Medicine, Hull York Medical School, Durham University and Peninsula Medical School). The views expressed are those of the authors and not necessarily those of the NHS, or the Department of Health.

Received: 30 August 2013 Accepted: 18 December 2013 Published: 23 December 2013

\section{References}

1. Coleman MP, Forman D, Bryant H, Butler J, Rachet B, Maringe C, Nur U, Tracey E, Coory M, Hatcher J, et al: Cancer survival in Australia, Canada, Denmark, Norway, Sweden, and the UK, 1995-2007 (the international cancer benchmarking partnership): an analysis of population-based cancer registry data. Lancet 2011, 377(9760):127-138.

2. Richards MA: The size of the prize for earlier diagnosis of cancer in England. Br J Cancer 2009, 101(S2):S125-S129.

3. Department of Health: Report on the self reported experience of patients from black and minority ethnic groups. 2009. https://www.gov.uk/ government/publications/experience-of-patients-in-black-and-minorityethnic-groups-2007-to-2009.

4. Ramirez AJ, Westcombe AM, Burgess CC, Sutton S, Littlejohns P, Richards MA: Factors predicting delayed presentation of symptomatic breast cancer: a systematic review. Lancet 1999, 353(9159):1127-1131.

5. Cuthbertson SA, Goyder EC, Poole J: Inequalities in breast cancer stage at diagnosis in the trent region, and implications for the NHS breast screening programme. J Public Health 2009, 31(3):398-405.

6. Jack $\mathrm{RH}$, Davies EA, Moller $\mathrm{H}$ : Breast cancer incidence, stage, treatment and survival in ethnic groups in South East England. Br J Cancer 2009, 100(3):545-550.

7. Lyratzopoulos G, Neal RD, Barbiere JM, Rubin GP, Abel GA: Variation in number of general practitioner consultations before hospital referral for cancer: findings from the 2010 national cancer patient experience survey in England. Lancet Oncol 2012, 13(4):353-365.
8. Coupland VH, Lagergren J, Konfortion J, Allum W, Mendall MA, Hardwick $\mathrm{RH}$, Linklater $\mathrm{KM}$, Moller $\mathrm{H}$, Jack $\mathrm{RH}$ : Ethnicity in relation to incidence of oesophageal and gastric cancer in England. Br J Cancer 2012, 107(11):1908-1914.

9. National Cancer Intelligence Network: Cancer incidence and survival by major ethnic group, England, 2002-2006. London; 2009. http://www.ncin.org.uk/ publications/reports/.

10. The Commonwealth Fund: International profiles of health care systems. Australia, Canada, Denmark, England, France, Germany, Italy, the Netherlands, New Zealand, Norway, Sweden, Switzerland, and the United States; 2011. http://www.commonwealthfund.org/Publications/FundReports/2011/Nov/International-Profiles-of-Health-Care-Systems-2011.aspx.

11. Olesen $F$, Hansen RP, Vedsted $P$ : Delay in diagnosis: the experience in Denmark. Br J Cancer 2009, 101(S2):S5-S8.

12. Rodgers M, Sowden A, Petticrew M, Arai L, Roberts H, Britten N, Popay J: Testing methodological guidance on the conduct of narrative synthesis in systematic reviews effectiveness of interventions to promote smoke alarm ownership and function. Evaluation 2009, 15(1):49-73.

13. Weller D, Vedsted P, Rubin G, Walter FM, Emery J, Scott S, Campbell C, Andersen RS, Hamilton W, Olesen F, et al: The aarhus statement: improving design and reporting of studies on early cancer diagnosis. Br J Cancer 2012, 106(7):1262-1267.

14. Rajan SS, Lim JNW, Haq A: Late presentation and management of South Asian breast cancer patients in west yorkshire, United Kingdom. Asian Pac J Cancer Prev 2011, 12(6):1615-1618.

15. Meechan G, Collins J, Petrie K: Delay in seeking medical care for self-detected breast symptoms in New Zealand women. New Zealand Med J 2002, 115(1166):U257.

16. Velikova G, Booth L, Johnston C, Forman D, Selby P: Breast cancer outcomes in South Asian population of West Yorkshire. Br J Cancer 2004, 90(10):1926-1932.

17. Nosarti C, Crayford T, Roberts JV, Elias E, McKenzie K, David AS: Delay in presentation of symptomatic referrals to a breast clinic: patient and system factors. Br J Cancer 2000, 82(3):742-748.

18. Neal RD, Allgar VL: Sociodemographic factors and delays in the diagnosis of six cancers: analysis of data from the "national survey of NHS patients: cancer". Br J Cancer 2005, 92(11):1971-1975.

19. Sadler GJ, Jothimani D, Zanetto U, Anderson MR: The effect of ethnicity on the presentation and management of oesophageal and gastric cancers: a UK perspective. European J Gastroenterol Hepatol 2009, 21(9):996-1000.

20. Metcalfe C, Evans S, Ibrahim F, Patel B, Anson K, Chinegwundoh F, Corbishley C, Gillatt D, Kirby R, Muir G, et al: Pathways to diagnosis for black men and white men found to have prostate cancer: the PROCESS cohort study. Br J Cancer 2008, 99(7):1040-1045.

21. Neal RD: Do diagnostic delays in cancer matter [quest]. $\mathrm{Br} J$ Cancer 2009, 101(S2):S9-S12.

22. Mitchell E, Macdonald S, Campbell NC, Weller D, Macleod U: Influences on pre-hospital delay in the diagnosis of colorectal cancer: a systematic review. Br J Cancer 2007, 98(1):60-70.

23. Elliss-Brookes L, McPhail S, Ives A, Greenslade M, Shelton J, Hiom S, Richards $M$ : Routes to diagnosis for cancer - determining the patient journey using multiple routine data sets. Br J Cancer 2012, 107(8):1220-1226.

24. Potter S, Govindarajulu S, Shere M, Braddon F, Curran G, Greenwood R, Sahu AK, Cawthorn SJ: Referral patterns, cancer diagnoses, and waiting times after introduction of two week wait rule for breast cancer: prospective cohort study. BMJ 2007, 335:288-291.

doi:10.1186/1471-2296-14-197

Cite this article as: Martins et al:: Ethnic inequalities in time to diagnosis of cancer: a systematic review. BMC Family Practice 2013 14:197. 